\title{
Study on Cultural Identity from the Comparison Between "A House for Mr. Biswas" and "The Joy Luck Club"*
}

\author{
Jieqiong Duan \\ Xi'an FanYi University \\ Xi'an, China 710105
}

\begin{abstract}
The issue of identity is closely related to cultural and traditional issues. From the perspective of the cultural conflicts of immigrants, this paper explores the dilemma choice of traditional culture and the culture of immigrant destination country from the perspective of the protagonist's choice, the manifestation of conflict and the attitude towards conflict.
\end{abstract}

\section{Keywords—cultural identity; cultural conflict}

\section{INTRODUCTION}

Identity means "homoousia". Everyone has a sense of self-consciousness, a pursuit of unity of personality, and a convergence of ideals in a certain life. If you can't successfully identify who you are, the purpose of your life, and the attitudes to treat others, it will lead to "role confusion" and the subsequent failures of life. "A House for Mr. Biswas" and "The Joy Luck Club" all describe the immigrant life. The protagonists in both two works are contradictory. They cannot give up the inherent culture, and cannot be integrated into a new culture. They have always been in the cracks of culture, and have no cultural identity. They don't know who they are, and feel overwhelmed. The issue of identity is closely related to cultural and traditional issues. A person often establishes his or her identity through traditional conscious or spontaneous attitude. When a person is at a loss in the opposition and collision of various cultural traditions, he or she will inevitably fall into the crisis of identity.

\section{The CHOICE OF CHARACTERS IN "A House FOR Mr. BISWAS" AND "THE JOY LUCK CLUB"}

The protagonist of "A House for Mr. Biswas" is Mr. Biswas. Throughout this book, he pursues the house. And this book expresses the immigrants' pursuit of the lost spiritual home. "The Joy Luck Club" describes the fate of twelve women in three generations, mainly telling the stories of eight women of the second generation and the third generation living in a foreign country. It shows the conflicts of different cultures they represent. "A House for $\mathrm{Mr}$.

*This paper is the result of an important university-level scientific research project of Xi'an FanYi University, "Research on the interaction between college students' cultural literacy and "bottom-line thinking" (18A01).
Biswas" takes a son-in-law of the family of Tours. Mr. Biswas is the main description object, telling the relationship between him and his wife, the relationship between him and the actual ruler of the family. The focus is to write his life experience from his perspective. "The Joy Luck Club" describes three mothers, Xu Anmei, Gong Linda, and Ying Ying, telling their memories of their mothers, memories of their life experiences in China, and the memory of $\mathrm{Wu}$ Suyun's daughter of her mother with the mouth of the mother. Totally, this book has told eight mothers' stories. In addition, there are four daughters, Jun, Rose, Vivian, and Lina, telling their respective lives and their childhood stories. It can be said that there is only one protagonist in "A House for Mr. Biswas", which is a story on a man's pursuit of a house. In "The Joy Luck Club", the mothers and daughters of second generation and third generation are all the protagonists. It is a story about the conflict between the four mothers and daughters.

\section{ThE SPECIFIC MANIFESTATIONS AND CAUSES OF Cultural CONFLiCTS}

"A House for Mr. Biswas" mainly describes the conflict between Mrs. Tours and her son-in-law, Mr. Biswas, which is an intrinsic conflict. In the early stage, it is the conflict between Seth and Biswas. Among them, it includes the conflict between Biswas and his wife, and the conflict between Biswas and other sons-in-law. Biswas is always incompatible with this big family he entered. He can't find the feeling of home. In the big family, he has no dignity or status. There is no one caring whether he appears or disappears. Usually, there is no family member thinking of him. However, when the family wants to make fun of teasing, people will think of him. In that family, he shows extreme self-esteem and inferiority. He has no rights to name the first child. The Tours family has already given his child a name and a birth certificate. No one care the name he is willing to give his daughter. No one calls his child with the named name. For this reason, he is very angry. However, he has no choice. As a Christmas present, the toy house that cost him a month's salary is ruined by Shama under the shackles and deliberate alienation of others. He roared "Shama, You bitch. Are you demolished the toy house?" The voice began to grow bigger: "Who you want to please?" In a blink, his anger 
suddenly disappeared without a trace. His screams echoed in his mind, making him shocked, jealous and exhausted. He is speechless. In the big house of Tours family, it was extremely noisy and crowded. Biswas doesn't have any personal space. At the bottom of the whole family, Biswas was excluded from the mainstream of the whole family. When he and his wife lived in the hunting village, his wife also called the house of Tours home. The house of the hunting village is regarded as a leisure place. She does not agree with the house where living with Biswas together. That is, his wife did not respect him. He did not have any dignity. Therefore, he wants to escape again and again, and wants to have his own house, his own space, and realize his independence of dignity, face, status and personality. There is no problem of dignity, face, status and personality independence in the relationship between mother and daughter in "The Joy Luck Club". Mothers love daughters, and daughters love mothers. However, they often do not know how to express themselves because of cultural differences. They can't understand each other. For example, $\mathrm{Wu}$ Suyun asked Jun to play the piano, and Jun expressed her resistance. "I don't have to do what you want. I am not your slave. We are not in China." "I don't want to be your daughter." After mother died, "My mother and I never really understood each other. We translated each other's meaning. I don't always seem to understand my mother's words, but my mother can always hear the implication in my words." "I never believe that I can be anyone I want to be, I can only be myself." The daughters always laugh at the mother's lame English. They believe that the mothers are unresponsive, and have a heavy heart. The daughters don't understand why the mothers want to do the Joy Luck Club, which seems to be "the secret party of the KKK". The mothers always want their daughters to become the ones who the mother wants them to be. The mothers pay all attention to them, and are strict with them. If they make the success, the mothers will show off the achievements. However, the daughters cannot understand why they want to do so. In short, there is no love in "A House for Mr. Biswas", and the relationship within the family is cold. There are suspicion, ridicule, and isolation among the members of the family. The conflict is the unconformity between Biswas and the Tours family. Originally, the entire mansion was a closed space independent of Trinidad. Without communication with the outside world, he was excluded from the whole family. Biswas' isolation is prominent. He has no home, no sense of security, no love, no dignity, no social status, or no spiritual home. "Life is meaningless, and he has no place to live." In short, he is a loner without love. The conflict within the family in "A House for Mr. Biswas" indirectly reflects that Biswas is isolated from colonial culture. He lives in a place of immigration, is isolated from the local culture, and is excluded from the local culture of the big family. It is equivalent to saying that he has suffered double cultural barrier. His loneliness is prominent. At this level, conflicts and collisions between Indian culture and colonial culture can also be seen. In "The Joy Luck Club", there is full of love between mother and daughter. The so-called conflict is the difference in age and culture between each other. Differences in language, way of thinking, expression, customs, values, and outlook on life have caused communication barriers and mutual incomprehension between mother and daughter. It is a direct and obvious manifestation of the conflict between immigration culture and local culture, that is, the Sino-US cultural conflict.

In "A House for Mr. Biswas", the Tours family was segregated from Trinidad society. This is not because the Trinidad society rejects them, and the Tours family adopts a passive integration into the society. They adopt a way of divergence, rejection, and resistance. They don't want to accept local culture. And they are very sincere and stubborn in sticking to local culture. And many local Indian immigrants have adopted this approach. However, when they have the opportunity to return to India, they choose to stay in this temporary residence. They are contradictory. They cannot give up the inherent culture, and they can't integrate into the local culture. In the cracks of culture, there is no cultural identity. They have no spiritual habitat that belongs to themselves, wandering and drifting. They are like duckweed, naturally feeling lonely. They are dependent, and have no sense of belonging. It is from a cultural point of view, rising to the height of overall human care. We can also find resonance. As a person, a social person, Biswas has no private space or no wife. The children don't respect him. The members of the family don't care his social status. It can be said that he has no dignity. And he has not given up his efforts on self-esteem. He did not give up, which made him extremely painful. Amy Tan, the author of "The Joy Luck Club", is the only Chinese girl in the class from the third grade of primary school to the high school. She always wants to get approval. However, "the difference makes me feel the looks and bloodlines of the oriental people, and cultural traditions often make me distressed and shy." The four daughters of the third generation in "The Joy Luck Club" are born in the United States. They receive American culture from an early age, speak fluent English, and are proud of that They have been completely westernized and psychologically recognize American culture. They also hope that they can get the recognition of American culture. When they are young, they believe that they are Americans. In fact, they are more integrated into American society than their mothers. However, when they grow up and go through a lot of things, they gradually understand their mothers, and gradually recognize the marginal status. American culture is exclusive to them. Before going to the grand party held by her boyfriend's family, Rose believes that she is an American. It was no different from others. With the expression of Ted's mother, she is aware. The life experiences of the daughters are the process of identity and the experience of Sino-US cultural confrontation and integration. After Jun's mother died, she understands her mother's desire to be placed on her Rose lost her opinion after marriage. The forbearance makes $\mathrm{Xu}$ Anmei feel that she is carrying the mother's blood, telling Rose about the past life of her and her mother. The mother and daughter reached the communication in mind. Rose knew how to go right in the marriage. The daughters realized that only by understanding Chinese culture can they understand their mother and understand themselves. The mothers of the second generation live in the United States. However, they still insist on many traditional things. They 
are not recognized. In order to regain the ego and survive, they establish the Joy Luck Club, where they play mahjong, cook, and tell stories. The mothers find a continuation of the spirit and facilitate the mothers to find a reasonable basis for establishing their position and identity. They are blocked from the door of American culture, and they cannot integrate in the society.

\section{The OVERALl ATMOSPHERE OF "A HOUSE FOR MR. BISWAS" AND "THE JOY LUCK CLUB"}

In the overall, "A House for Mr. Biswas" is repressive, "The Joy Luck Club" is repressive in the former part, and the latter part is easy. Mr. Biswas has always wanted to own a house of his own life, and he has been fighting for it. He has three houses, and the first two houses are all burned down. Of course, the first two houses can be house frame. This is Mr. Biswas' hard work and desire for a real house. The last house he owns has such problems. However, he finally adapts to it. He did not fully own the house until he died. He still owes $\$ 3,000$, which means that his children Saiwei and Anand, the next generation, will continue to repay the loan for him. "The Joy Luck Club" tells the story of four families of women according to the order of mahjong. The women of first generation live in China, women of the second generation immigrate to the United States in adulthood, and women of the third generation are born in the United States. There is a conflict between the mothers of second generation and daughters of third generation representing different cultures between China and the United States. And this conflict between different cultures is inevitable. When the daughters grow up, the mother passed away, or the daughters stepped into marriage, became the mothers, they experienced many things, gradually understood their mothers. Their mothers have lived in the United States for many years. They will communicate with each other. Finally, they will reach a consensus.

\section{CONCLUSION}

In short, the two books have written the living conditions and mental state of immigrants. Different immigration countries and original cultures have affected the conditions of the immigrants. This contains many contents, such as the rise of world politics, economic, and cultural globalization trend. The rise of China's economic status has gradually lifted. The overseas Chinese have the status. In any case, both of them truly reflect the identification of cultural identity in different countries. With the self-identification standards such as "Who am I?" "Where am I from?" "Where am I going?", people or cultures have a certain direction when they get along with the world. On the contrary, people have the identify crisis, they will lose this direction. Li Hangyu confessed this contradiction in "The Embarrassment of Culture": "On the one hand, it is very clear how badly the national consciousness I have suffered. On the other hand, I have to stubbornly defend it. I am afraid that there is nothing left in addition to it." It should be said that this is not only a dilemma between the traditional culture and the culture of immigrants, but also a profound paradox in historical choice and cultural judgment.

\section{REFERENCES}

[1] Diao Donglin. On the "space" in the narrative of novels in the early 1980s[D]. Guangzhou: Jinan University, 2006.

[2] Yao Xinyong. The journey of pilgrimage: poetry, nationality and cultural conflict_— On the Tibetan Chinese poetry in the transition period[J]. Minority Literature Research, 2008(2)

[3] Du Yunhui. Research on the cultural philosophy of Zhang Dainian[M].Beijing:China Social Sciences Press, 2014 